\title{
Effect of Potassium Permanganate on Physico-Chemical Changes and Shelf Life of Mango (Mangifera indica L.)
}

\author{
M. Ittefaqul Azad ${ }^{1}$, M. Golam Mortuza ${ }^{2 *}$, N. Ahktar Nahar ${ }^{3}$, Shamina Huq ${ }^{4}$ and M. Ashraful Alam ${ }^{2}$ \\ ${ }^{1}$ Department of Agriculture Extension, Rajshahi, Bangladesh, ${ }^{2}$ Regional Horticulture Research \\ Station, Bangladesh Agricultural Research Institute, Chapai Nawabganj; Bangladesh, ${ }^{3}$ Leaf Project, \\ Inter cooperation, Rajshahi, Bangladesh, ${ }^{4}$ Stamford University, Dhaka, Bangladesh \\ * Corresponding author:
}

\begin{abstract}
Mango fruits (cv. Fazli and Khirsapat) were treated with 3 dosages (5, 10 and 20g) of Potassium permanganate (PP) and kept in sealed polythene bags at normal room temperature $\left(28-33{ }^{0} \mathrm{C}\right)$. It was observed that PP had little effect on colour development in both the cultivars. All the treated fruits remained green upto 6 days of storage. All the treatments delayed ripening of mango fruits from 2.37 to 4.84 days as compared with untreated control. Fruits treated with $5 \mathrm{~g}$ PP required longer time for ripening followed by 10 and $20 \mathrm{~g}$. The results indicated that PP had no effect on weight loss and was not able to improve appearance or eating quality of the fruits. Mango fruits stored in polyethylene bag showed lower TSS and sugar contents and subsequently possessed lower ratings for eating quality which cause less sweet and slightly bitter taste. The longest shelf life was noted in fruits treated with $20 \mathrm{~g}$ followed by $10 \mathrm{~g}$ and $5 \mathrm{~g}$ PP although there were no significant differences among the treatments.
\end{abstract}

Keywords: Potassium permanganate, colour development, shelf life, mango,

\section{Introduction}

Mango (Mangifera indica L.) is one of the important fruits grown in Bangladesh. Its production is 2,42,690 ton from 51,012 ha.(BBS, 2005). High post harvest losses especially in Bangladesh because of its high perishability and climacteric pattern of respiration have been reported (Rubbi et al., 1985, Quroshi and Meah, 1991). After harvest, fruits undergo many physiological and biochemical changes during storage. Apart from those changes, microbial decay also contributes to postharvest losses during ripening and storage. The storage life of a fruit could be prolonged significantly through slowing down the ripening process and controlling the microbial decay. Storage quality of mango is highly dependent upon the stage of harvesting. Mangoes when harvested at later stages had reduced shelf life, while early harvesting caused more weight loss but showed better storability (Shahjahan et al., 1994).
Storage of mango in polythene bags containing potassium permanganate (PP) at ambient temperature of $20-30{ }^{0} \mathrm{C}$ was found to delay ripening by five days (Stead and Chithambo, 1980). Additionally, no differences in quality were noted between fruits stored in bags and stored in air. Philippine mangoes stored for 3 weeks at $10{ }^{0} \mathrm{C}$ in polythene bags, with and without ethylene absorbents, ripened to normal colour, texture and flavour when subsequently treated with ethylene (Esguerra et al., 1978). Similar response has been shown for Dashehari mangoes (Garg et al., 1976). The purpose of using potassium permanganate in the polythene bag was to absorb ethylene produced by the fruit during ripening process. The present study was undertaken to determine the feasibility of using PP as ethylene absorbent for delayed ripening as well as extending shelf life of harvested mango fruits. 


\section{Materials and Methods}

Mango fruits were collected from the Regional Horticulture Research Station farm of Chapai Nawabgonj. Matured but green fruits of cultivar Khirsapat and Fazli were harvested with similar size and shape. Just after harvest, the fruits were kept in sealed polythene bags with three doses (0, 10, and $20 \mathrm{~g}$ per 10 fruits) of PP. The experiment was laid out in a factorial completely randomized design with three replications. It was kept in a small piece of cloth which was placed in sealed polythene bags according to the treatment. Treated and untreated fruits were kept in room temperature $\left(28-34^{0} \mathrm{C}\right)$. Data on colour development, days required for ripening, weight loss and general appearance were taken at regular intervals. Eating quality, general appearance of fruits and total soluble solids were measured at full ripen stage. General appearance and eating quality of the fruit is the sum of skin colour and texture. It was determined at the optimum ripe stage using 1-9 scale. Shelf life was determined by counting the date from harvest to its last edible stage and was expressed in day. Data were analyzed and treatment means were separated using DMRT.

\section{Results and Discussion}

\subsection{Colour development}

Potassium permanganate had little effect on colour development (Table 1) in the mango varieties. All the treated fruits remained green up to 6 days of storage. Untreated fruits stored in air developed a trace of yellow colour at the $6^{\text {th }}$ day in both the cultivars. Untreated control fruits of Khirsapat stored in air or in polythene bag became unfit for consumption after 6.00 and 6.33 days, respectively. The fruits of Fazli under the same treatments became unfit for consumption after 8.16 and 8.60 days, respectively. After 9 days, Khirsapat fruits treated with 5,10 or $20 \mathrm{~g}$ PP developed greenish yellow colour. At the same storing period, Fazli exhibited a trace of yellow colour for the same treatments. After 12 days, Khirsapat retained the previously developed colour at $T_{2}, T_{3}$ and $T_{4}$ treatments. On the other hand, Fazli developed yellowish green in $\mathrm{T}_{2}$ treatment and greenish yellow colour in $\mathrm{T}_{3}$ and $\mathrm{T}_{4}$ treatments.

Table 1: Development of colour in harvested mango fruits as affected by $\mathrm{KMnO}_{4}$ treatment

\begin{tabular}{|c|c|c|c|c|c|c|c|c|}
\hline \multirow[t]{2}{*}{ Cultivar } & \multirow{2}{*}{$\begin{array}{l}\text { Amount of } \\
\mathrm{KMnO}_{4}(\mathrm{~g})\end{array}$} & \multicolumn{7}{|c|}{ Days of storage } \\
\hline & & 0 & 3 & 6 & 9 & 12 & 15 & 18 \\
\hline \multirow[t]{5}{*}{ Khirsapat } & Control & Green & Green & TY & -- & -- & -- & -- \\
\hline & 0 & Green & Green & Green & -- & -- & -- & -- \\
\hline & 5 & Green & Green & Green & GY & GY & GY & -- \\
\hline & 10 & Green & Green & Green & GY & GY & GY & -- \\
\hline & 20 & Green & Green & Green & GY & GY & GY & -- \\
\hline \multirow[t]{5}{*}{ Fazli } & Control & Green & Green & TY & -- & -- & -- & -- \\
\hline & 0 & Green & Green & Green & -- & -- & -- & -- \\
\hline & 5 & Green & Green & Green & $\mathrm{TY}$ & GY & GY & GY \\
\hline & 10 & Green & Green & Green & $\mathrm{TY}$ & GY & GY & -- \\
\hline & 20 & Green & Green & Green & $\mathrm{TY}$ & GY & GY & -- \\
\hline
\end{tabular}

TY: Trace of Yellow, GY= Greenish Yellow 


\subsection{Ripening}

Ripening of mango fruits was significantly influenced by PP. All the treatments delayed ripening of mango fruits from 2.37 to 4.84 days as compared with untreated control (Table 2). The maximum delay (10 days) in ripening was recorded in fruits treated with $5 \mathrm{~g}$ PP. Higher doses (10 or $20 \mathrm{~g}$ ) of PP were not able to delay ripening as recorded in $5 \mathrm{~g}$. Significant variation in fruit ripening was also noted in mango varieties under investigation. Fruits of the cv. Fazli required 8.76 days while Khirsapat required 6.61 days for optimum ripening.

Significant interactions in ripening time were noted among the treatment combinations. It ranged from 4.06 to 11.13 days. The longest time (11.13 days) was required the ripening in fruits treated with $5 \mathrm{~g}$ PP (Table 3). It was observed that Fazli required longer period for ripening than Khirsapat in all the corresponding treatments. In Khirsapat, fruits treated with $5 \mathrm{~g}$ PP resulted in longer period for ripening (8.86 days) followed by 10 and $20 \mathrm{~g}$ (7.53 and 7.46 days). Untreated fruits ripened earlier than the treated one in both the cultivars. Similar trend in ripening was noted in Fazli. The longest time was (11.13 days) needed in fruits treated with $5 \mathrm{~g}$ PP followed by 10 and $20 \mathrm{~g}$.

The results revealed that PP delayed ripening of mango fruits. Similar results have been reported by Stead and Chithambo (1980). They noted delayed ripening by 5 days in mango fruits stored in polythene bags with PP. Wills et al. (1989) reported similar results in banana fruits. The commencement of ripening in climacteric fruits like mango is accompanied with an increased ethylene production by the fruit itself. The natural ethylene production at the time of ripening can be arrested with PP, a strong oxidizing agent thus helps in retardation of ripening of mango fruits in the present study. Mango fruits which required more time to ripe are suitable for long distance transport and facilitate long time marketing. More delay in ripening of Fazli was probably its varietal characteristics.

Table 2. Effect of $\mathrm{KMnO}_{4}$ treatment on physico-chemical characters of two cultivars of mango

\begin{tabular}{|c|c|c|c|c|c|c|c|c|}
\hline \multirow[t]{2}{*}{ Treatment } & \multirow{2}{*}{$\begin{array}{l}\text { Ripenin } \\
\text { g time } \\
\text { (days) }\end{array}$} & \multicolumn{3}{|c|}{ Weight loss (\%) } & \multirow{2}{*}{$\begin{array}{l}\text { General } \\
\text { Appearan } \\
\text { ce }\end{array}$} & \multirow{2}{*}{$\begin{array}{l}\text { Eating } \\
\text { quality }\end{array}$} & \multirow{2}{*}{$\begin{array}{l}\text { TSS } \\
(\% \\
\text { Brix })\end{array}$} & \multirow{2}{*}{$\begin{array}{l}\text { Shelf } \\
\text { Life } \\
\text { (days) }\end{array}$} \\
\hline & & 3 days & 6 days & $\begin{array}{l}9 \\
\text { days }\end{array}$ & & & & \\
\hline Khirsapat & $6.6 \mathrm{~b}$ & $1.91 \mathrm{a}$ & $2.18 \mathrm{a}$ & $2.39 \mathrm{a}$ & $3.15 \mathrm{a}$ & $4.15 \mathrm{a}$ & $17.30 \mathrm{a}$ & $12.53 \mathrm{~b}$ \\
\hline Fazli & $8.76 \mathrm{a}$ & $1.27 \mathrm{~b}$ & $1.57 \mathrm{~b}$ & $1.82 \mathrm{~b}$ & $3.29 \mathrm{a}$ & $4.32 \mathrm{a}$ & $15.37 \mathrm{~b}$ & $14.05 \mathrm{a}$ \\
\hline Control & $5.1 \mathrm{~d}$ & $2.62 \mathrm{a}$ & $3.63 \mathrm{a}$ & $4.17 \mathrm{a}$ & $3.19 \mathrm{a}$ & $6.03 \mathrm{a}$ & $19.44 \mathrm{a}$ & $7.08 \mathrm{~b}$ \\
\hline $\mathrm{KMnO}_{4}(0 \mathrm{~g})$ & $6.12 \mathrm{c}$ & $1.34 \mathrm{~b}$ & $1.44 \mathrm{~b}$ & $1.59 \mathrm{~b}$ & $3.20 \mathrm{a}$ & $4.12 b$ & $15.44 b$ & $7.47 \mathrm{~b}$ \\
\hline $\mathrm{KMnO}_{4}(5 \mathrm{~g})$ & $10.00 \mathrm{a}$ & $1.35 \mathrm{~b}$ & $1.43 \mathrm{~b}$ & $1.60 \mathrm{~b}$ & $3.21 \mathrm{a}$ & $4.00 \mathrm{~b}$ & $15.50 \mathrm{~b}$ & $17.18 \mathrm{a}$ \\
\hline $\begin{array}{l}\mathrm{KMnO}_{4} \\
(10 \mathrm{~g})\end{array}$ & $8.63 b$ & $1.33 b$ & $1.43 b$ & $1.60 \mathrm{~b}$ & $3.24 \mathrm{a}$ & $4.03 b$ & $15.51 b$ & $17.81 \mathrm{a}$ \\
\hline $\begin{array}{l}\mathrm{KMnO}_{4} \\
(20 \mathrm{~g})\end{array}$ & $8.53 b$ & $1.32 \mathrm{~b}$ & $1.46 \mathrm{~b}$ & $1.59 \mathrm{~b}$ & $3.27 \mathrm{a}$ & $4.02 \mathrm{~b}$ & $15.78 b$ & $19.95 \mathrm{a}$ \\
\hline $\mathrm{CV}(\%)$ & 3.18 & 3.74 & 5.64 & 4.35 & 12.10 & 7.49 & 4.10 & 12.83 \\
\hline
\end{tabular}

Values followed by the same letter (s) in a column for two cultivars and for treatments are not significantly different $(\mathrm{P}<0.05)$ according to DMRT. Percentage data were transformed into square root before analysis. 
Table 3. Interaction effect of cultivars and $\mathrm{KMnO}_{4}$ treatment on physico-chemical characters of mango fruits

\begin{tabular}{|c|c|c|c|c|}
\hline $\begin{array}{c}\text { Treatment } \\
\text { combination }^{\mathrm{a}}\end{array}$ & $\begin{array}{l}\text { Ripening time } \\
\text { (Days) }\end{array}$ & $\begin{array}{c}\text { General } \\
\text { appearance }^{b}\end{array}$ & Eating quality $^{\mathrm{b}}$ & TSS ((\%) Brix) \\
\hline $\mathrm{V}_{1} \mathrm{~T}_{0}$ & $4.06 \mathrm{~d}$ & $3.13 \mathrm{a}$ & $6.40 \mathrm{a}$ & $21.29 \mathrm{a}$ \\
\hline $\mathrm{V}_{1} \mathrm{~T}_{1}$ & $5.13 \mathrm{~d}$ & $3.13 \mathrm{a}$ & $4.03 \mathrm{~b}$ & $16.29 b$ \\
\hline $\mathrm{V}_{1} \mathrm{~T}_{2}$ & $8.86 b c$ & $3.13 \mathrm{a}$ & $4.02 \mathrm{~b}$ & $16.30 \mathrm{~b}$ \\
\hline $\mathrm{V}_{1} \mathrm{~T}_{3}$ & $7.83 \mathrm{c}$ & $3.17 \mathrm{a}$ & $4.03 b$ & $16.34 b$ \\
\hline $\mathrm{V}_{1} \mathrm{~T}_{4}$ & $7.46 \mathrm{c}$ & $3.18 \mathrm{a}$ & $4.03 \mathrm{~b}$ & $16.27 b$ \\
\hline$\overline{V_{2} T_{0}}$ & $6.27 d$ & $3.26 \mathrm{a}$ & $5.60 \mathrm{ab}$ & $17.58 \mathrm{a}$ \\
\hline $\mathrm{V}_{2} \mathrm{~T}_{1}$ & $7.10 \mathrm{c}$ & $3.27 \mathrm{a}$ & $4.00 \mathrm{~b}$ & $14.58 b$ \\
\hline $\mathrm{V}_{2} \mathrm{~T}_{2}$ & $11.13 \mathrm{a}$ & $3.28 \mathrm{a}$ & $3.99 b$ & $14.70 \mathrm{~b}$ \\
\hline $\mathrm{V}_{2} \mathrm{~T}_{3}$ & $9.73 b$ & $3.31 \mathrm{a}$ & $4.03 b$ & $14.68 b$ \\
\hline $\mathrm{V}_{2} \mathrm{~T}_{4}$ & $9.60 \mathrm{~b}$ & $3.35 \mathrm{a}$ & $4.00 \mathrm{~b}$ & $15.28 \mathrm{~b}$ \\
\hline $\mathrm{CV}(\%)$ & 3.18 & 12.10 & 7.49 & 4.10 \\
\hline
\end{tabular}

Values followed by the same letter(s) in a column are not significantly different $(\mathrm{P}<0.05)$ according to DMRT.

a. $\mathrm{V}_{1}=$ Khirsapat, $\mathrm{V}_{2}=$ Fazli, $\mathrm{T}_{0}=$ Control (open store) $\mathrm{T}_{1}=$ Control (store in polyethylene bag), $\mathrm{T}_{2}=\mathrm{KMnO}_{4}$ $(5 \mathrm{~g}), \mathrm{T}_{3}=\mathrm{KMnO}_{4}(10 \mathrm{~g}), \mathrm{T}_{4}=\mathrm{KMnO}_{4}(20 . \mathrm{g})$.

b. Data were taken at optimum ripening stage.

\subsection{Weight loss}

Among the cultivars, Khirsapat lost more weight than Fazli in all stages of observation. After 3, 6 and 9 days of storage, Fazli lost weight of 1.27, 1.57 and $1.82 \%$, respectively while Khirsapat lost $1.91,2.18$ and $2.39 \%$ (Table 2). Treated fruits stored in polythene bags might have protected rapid loss of moisture content in the fruits.

Untreated fruits stored in air lost their weight very rapidly at all stages of storage as compared with treated fruits. The loss of weight was positively correlated with the passage of time with the highest loss noted after 9 days of storage. The amount of loss in fruits kept in polythene bags either treated with PP or not were insignificant. The results indicated that PP had no effect on weight loss. Treated fruits were kept in polyethylene bag which acted as a physical barrier to gas diffusion from fruit stomata which might cause the minimum weight loss in mango fruits. It is obvious that the vapour pressure differences between the fruit tissue and the surrounding atmosphere are reduced due to sealed polyethylene bags limiting the transpiration and consequently, the minimum loss in total weight of the fruit.

\subsection{Total soluble solids}

Total soluble solids (TSS) content of the mango fruits were significantly influenced by PP. Less amount of TSS was noted in PP treated fruits as compared with untreated fruits. Khirsapat contained higher TSS (17.30\%) than Fazli $(15.37 \%)$. The results indicated that Khirsapat was superior to Fazli in respect of TSS content which is the genetical characteristic of the cultivar. Similar results were also reported by Mondal et al. (1995). They reported $16.09 \%$ TSS in Fazli treated with PP after 6 days of storage.

Treatment combination exhibited significant interactions in TSS content (Table 3). It varied from 14.58 to $21.29 \%$. TSS contents were the highest in untreated control fruits stored in air in both the cultivars, Khirsapat $(21.29 \%)$ and Fazli $(17.58 \%)$. TSS contents of the fruits treated with any dose of PP in both the cultivars were statistically identical. The results revealed that the treated and untreated fruits within polyethylene bags possessed lower TSS as compared with control fruits stored in air. 
Lesser amount of TSS in the treated mango fruits might be due to environmental conditions prevailed in polyethylene bag in which the fruits were stored. It lowered the normal physicochemical activities responsible for conversion of starch through hydrolysis into simple sugars which is a major part of TSS.

\subsection{General appearance}

PP had no significant effect on the improvement of appearance of the mango fruits. Although higher doses of PP increased the score of appearance of the fruit, but it was insignificant. The cultivars did not show any significant differences in appearance. However, fruits of the cultivar Fazli scored higher value (3.29) than Khirsapat (3.15). The results indicated that treatment of mango fruits with $\mathrm{PP}$ have no significant effect on texture as well as skin colour of the fruits. The interactions among the treatment combinations were also insignificant. It was noted that Fazli showed slightly better than Khirsapat at all corresponding treatments, which may be due to its varietal characteristics.

\subsection{Eating quality}

Mango cultivars showed insignificant differences in eating quality. However, Khirsapat scored higher value (4.51) than Fazli (4.32). This might be its varietal characteristics.

Eating quality of the mango fruit was significantly affected by PP. The score ranged from 4.00 to 6.03 showing the highest (6.03) at control fruits stored in air and the lowest (4.00) at fruits treated with $5 \mathrm{~g}$ PP (Table 2). Eating quality of the mango fruits stored in polythene bags either treated or untreated with PP were similar. The lower score of treated fruits was perhaps due to the hindrance of normal physiological activities as the fruits were stored within the polyethylene bags during the study period. The mango fruits stored in polyethylene bag showed lower TSS and sugar contents and subsequently possessed lower ratings for eating quality, which cause less sweet and slightly bitter taste. Similar results were also reported by Mohiuddin et al. (1991), who reported that mango fruits showed slightly sour and bitter taste when treated with coating materials.

In treatment combinations, the highest score was recorded in untreated fruits stored in air in both the cultivars. The score of eating quality in all other treatment combinations were low as compared with the untreated control.

\subsection{Shelf life}

Shelf life of the mango fruits was significantly influenced by PP treatments. Shelf life of the treated fruits was positively correlated with the amount of PP used for treatment. The longest shelf life was recorded in fruits treated with $20 \mathrm{~g}$ followed by 10 and $5 \mathrm{~g}$. There were no significant differences in shelf life in fruits treated with 5, 10 or $20 \mathrm{~g}$ PP. Considering the cost of treatments, $5 \mathrm{~g}$ PP is much better as compared with other treatments used in this investigation. Significant difference in shelf life was noted among the cultivars. Longer shelf life of 14.72 days was recorded in Fazli while 12.53 days in Khirsapat. The difference might be due to their inherent genetical characteristics. Mondal et al. (1995) reported 22.4 days shelf life of Fazli mangoes treated with PP which is higher than that of our investigation. Shelf life of a mango fruit depends primarily on the storage temperature and maturity of the fruit at harvest. Yuniarti and Surardi (1992) also reported extended shelf life by retarding ripening time of mango fruits treated with PP.

The study indicated that shelf-life of the treated fruits were extended satisfactorily while eating quality (both the flavour and taste) of the fruit were deteriorated as compared with the untreated fruits due to PP treatment. To prevent the development of off flavour and taste, further investigation on the optimum dose and duration of pp treatment is necessary.

\section{Conclusions}

Mango fruits treated with of Potassium permanganate had little effect on colour development in Fazli and Khirsapat but delayed ripening as compared with untreated control. Mango fruits stored in polyethylene bag showed 
lower TSS and sugar contents which subsequently possessed lower ratings for eating quality which cause less sweet and slightly bitter in taste. To prevent the development of off flavour and taste, further investigation on the optimum dose and duration of treatment is necessary.

\section{References}

BBS (Bangladesh Bureau of Statistics). 2005. Statistical Year Book of Bangladesh. Bangladesh Bureau of Statistics. Ministry of Planning, Dhaka. p 156

Esguerea, E. B., Mendoza D. B. and Pantasico. E. B. 1978. Use of Perlite- $\mathrm{KMnO}_{4}$ insert as an ethylene absorbant. Philippine Journal of Science, 107:23-31.

Garg, R. C., Ram. H. B. and S. K. 1976. Effect of etheylene absorbants on the ripenign and keeping quality of mango of cv. Dasehari. Indian Food Packer, 30: 54-56.

Mohiuddin, A. B. M. Rahim, M. A., Gheyas F. and Farooque. A. M. 1991. A note on the prolongation of shelf life of mango (Mangifera indica L.) with some coating materials. Bangladesh Horticulture, 19(1): 45-47.

Mondal, M. F., Rahman M. A. and Pramanik. M. A. J. 1995. Effect of different postharvest treatments on physico-chemical changes and shelf life of mango. Bangladesh Horticulture, 23 (1\&2): 1-5.
Qurohsi, S. U. and Meah. M. B. 1991. Postharvest losses in mango owing to stemend rot. International Journal of Tropical Agriculture, 9 (2): 98-105.

Rubbi, S. F., Rahman M. A. and Rahman. K. Q. 1985. Studies on the processing and preservation of mango. Proc. $4^{\text {th }}$ National Symposium of Bangladesh Society for Horticultural Science, BARI, Gazipur, pp 138-148.

Shahjahan, M. S., Sheel, M. A., Zaman M. A. and Sakur. M. A. 1994. Optimization of harvesting maturities for major mango cultivars in Bangladesh. Bangladesh Journal Scientific Research, 12(2):209-215.

Stead, D. E. and Chithambo, G. S. G. 1980. Studies on the storage of tropical fruits in polyethylene bags. Lusso Journal of Science and Technology. (Malawi). 1:3-9.

Wills, R. B. H., McGlossan, W. B., Graham, D., Lee T. H. and Hall. E. G.1989. Postharvest: An Introduction to the Physiology and Handling of Fruits and Vegetables. An Avi Book, Van Nostrand Reinhold, New York, p.173.

Yuniarti and Suhardi. 1992. Ripening retardation of 'Arumanis' mango. Association of Southeast Asian Nations (ASEAN) Food Journal. 7 (4): 207-208. 